\title{
風カ発電サイト立地選定のための局所風況予測モデルの開発
}

\section{Development of Local Area Wind Energy Prediction Model for Selecting Suitable Site for Windmill}

\author{
村上周三 ${ }^{1)} \quad$ 持田 灯 ${ }^{2 !}$ 加藤信介 ${ }^{3)}$
}

Shuzo MURAKAMI, Akashi MOCHIDA, Shinsuke KATO

1. はじめに

近年の環境問題への関心の高まりから、風力エネル ギーが注目を集め、各分野で研究が進められている。 風力による発電量は風速の 3 乗に比例するので、地形 や樹木等により局所的に大きく変化する風速分布を正 確に予測し、風車の立地選定を適切に行うことが極め て重要となる。しかしながら、従来、広く用いられて いる代表的な風況予測モデルであるWAsP ${ }^{1)}$ $\mathrm{AVENU}^{2)}$ は Jackson-Hunt ${ }^{3)}$ により導入された線形理論 に基づいており、平坦な地形、あるいは傾斜角 5 度程 度より穏やかな斜面周辺の流れは比較的精度良く予測 することができるが、急峻な地形に適用することは困 難である 4) 6)注1)。従って、国土の多くの領域が急峻な 山岳地形で占められている我が国や地中海沿岸の地域 において、風況予測を正しく行うためには、線形化を 施されない原 Navier-Stokes 方程式に基づいた、より精
密なモデルが必要とされる。

筆者らは、近年、新エネルギー・産業技術総合開発 機構（NEDO）の研究プロジェクトの一環として、急 峻な山岳地形にも適用可能な局所的風況予測モデルの 開発進めている注2)。本プロジェクトでは実務への利用 が可能な計算負荷で、年平均風速を $10 \%$ 以内の誤差で 予測可能な数值予測システムの開発を目標としており、 1999 年度にはじまり、2002 年度に終了する予定である。 本稿では、現在までの本プロジェクトにおける活動と 成果について紹介する。

\section{2. プロジェクトの概要}

Figure 1 に本プロジェクトとここで開発される予測 システムの概要を示す。研究グループは、注 2 に示す ように、気象学、風工学、建築学、機械工学等の各分 野の専門家により構成されている。

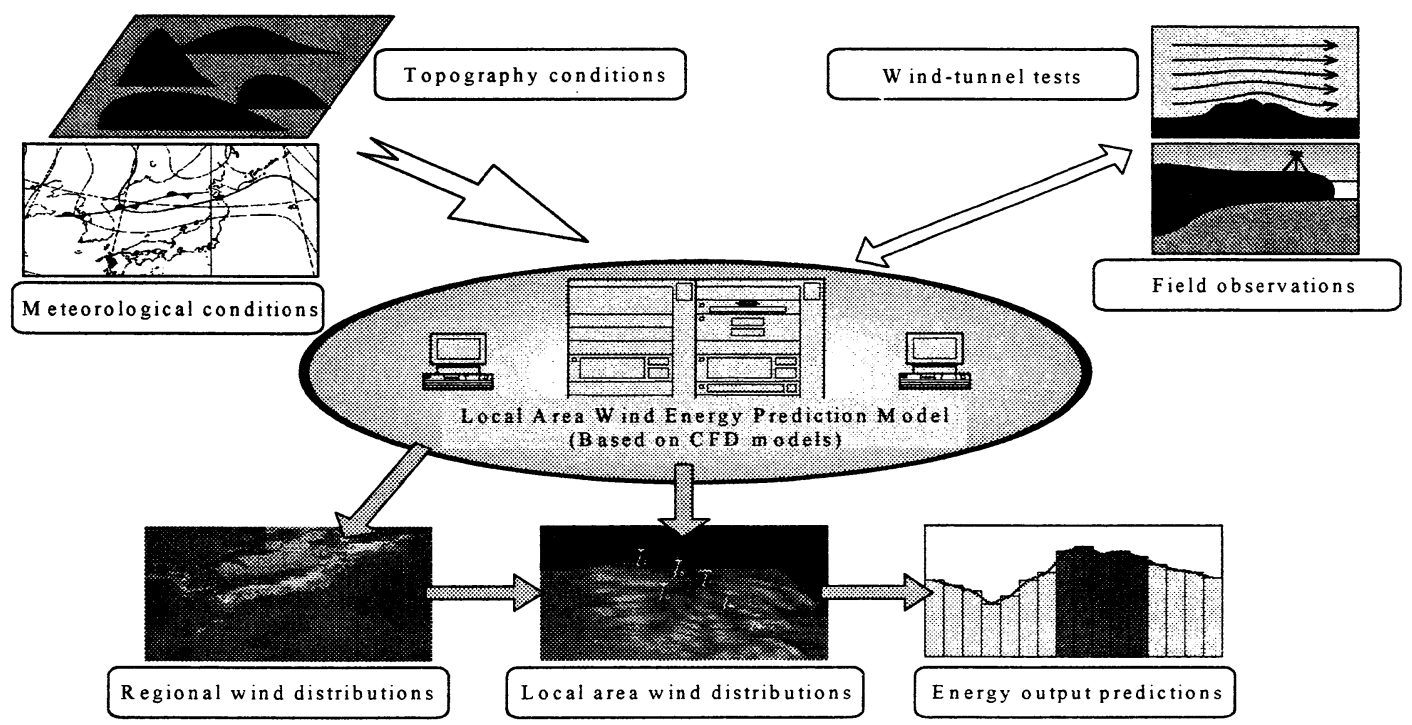

Figure 1 Development of the local area wind prediction model

1) 慶応義塾大学理工学部 教授 Professor, Keio University

2) 東北大学大学院工学研究科 助教授 Associate Professor, Tohoku University

3) 東京大学生産技術研究所 教授 Professor, University of Tokyo 


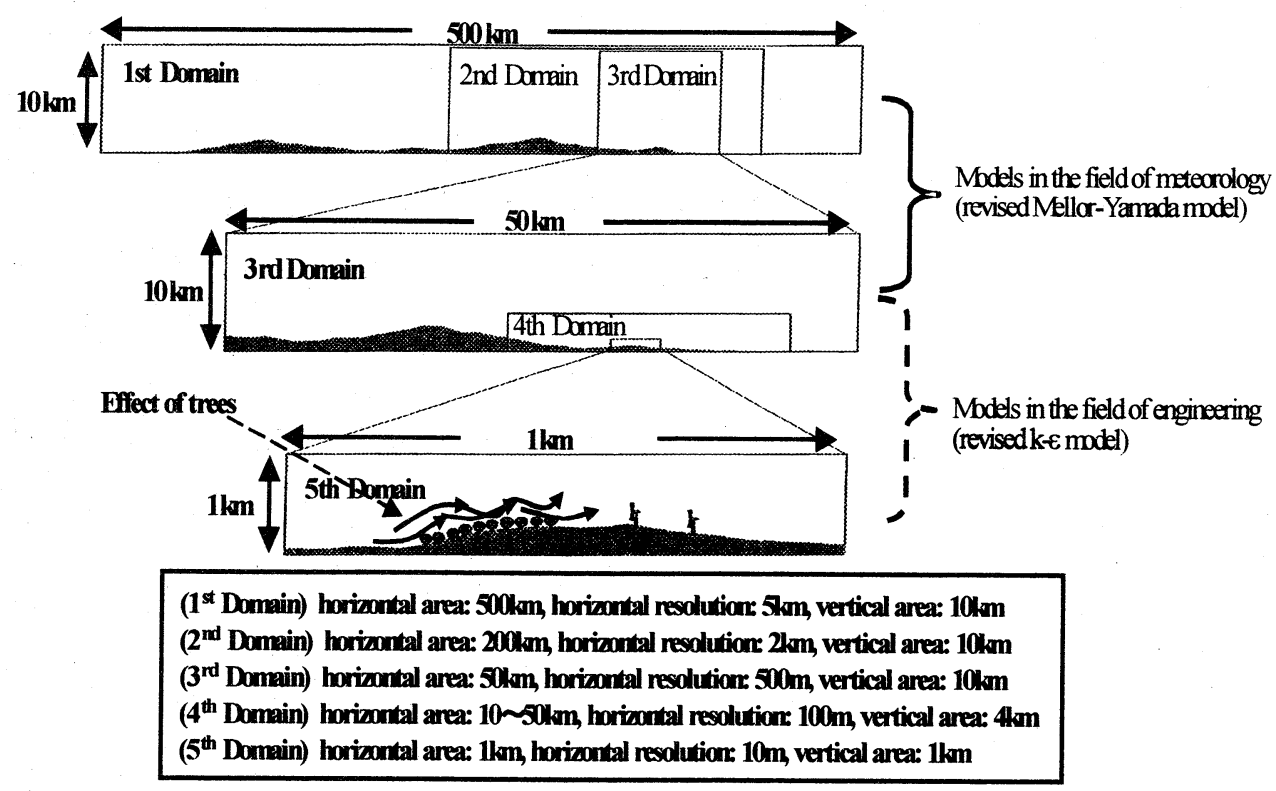

Figure 25 computational domains for multi-step wind simulation model

\subsection{5 段階の解析領域}

本研究では、Figure 2 に示すような 5 段階の解析領域 を考えている。最も大きい 1 次領域(1st Domain)は水平 距離 $500 \mathrm{~km}$ スケールの領域であり、気象庁予報結果の 格子点值(GPV: Grid Point Values)を初期值・境界值とす る解析を行う。そして 5 段階の Nesting Grid System に より、1〜5 次の領域を接続した解析を行う。ここで、 1 次〜 3 次領域では、気象分野の乱流モデルを用い、番内側の 5 次領域(水平距離 : $1 \mathrm{~km}$ スケール, 水平格子 間隔 : 約 $10 \mathrm{~m})$ では、工学分野のモデルを利用する。3 次領域と 5 次領域の中間に設けられた 4 次領域は、気 象分野のモデルと工学分野のモデルを接続するために 設けられた領域である。

\section{2 乱流モデル}

1 次〜3 次領域を対象としたモデルでは、運動量の輸 送方程式の他に温位、水分混合比の輸送方程式も解く。 そしてこれらの領域のための closure model としては、 後述する Mellor-Yamada の level 2.5 の改良版を用い、 乱流エネルギーの輸送方程式を解き、乱れの長さスケ 一ルは代数式より与える。4 次領域では、乱流モデル は 5 次領域と同様の改良型の $\mathrm{k}-\varepsilon$ モデルに変更するが、 $1 \sim 3$ 次領域同様に温位の輸送式を解く。浮力効果のモ デリングについては、 Mellor-Yamada の level 2.5 のモデ ルを参考に、これに対応する付加項を加えている。5 次領域では温位の輸送方程式は解かず、浮力の効果は 運動方程式の浮力項、 $\mathrm{k}$ 及び $\varepsilon$ の輸送方程式の浮力生 産項の值を 4 次領域の值から補間し、外力項として与 える。また、 1 次〜 3 次領域では、計算時間を短縮する
ために、静力学平衡主3)を仮定して圧力を求め、4 次、 5 次領域では、非静力学モデルを用いている。

\section{3 検証用データ}

本プロジェクトでは、数值モデルの開発と同時に、 丘陵地形、山岳地形、崖地形を対象とする詳細な風洞

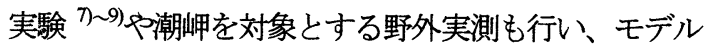
検証のためのデータの取得も進めている。

\section{3. 解析モデルの榗要および結果}

\subsection{1 次〜3 次領域 (改良型 Mellor-Yamada モデル)}

Figure 3 に 1 次〜 3 次領域の計算によって得られた 潮岬周辺の風況の予測結果を示寸。これらの領域の解 析は、前述のように Meller-Yamada の level 2.5 の改良 版に基づいているが、具体的には日本気象協会によっ て開発された局地気象モデル (ANEMOS: Area-oriented Numerical simulation and Environmental assessment MOdeling System) を利用している。ただし、従来の ANEMOS では乱流クロージャーモデルとして Mellor-Yamada のレベル $2.5^{10)}$ が利用されていたが、本 解析では、中西 ${ }^{11)} に よ り$ 提案された改良型のレベル 2.5 のモデルを用いている。この改良モデルでは、 Mellor-Yamada のモデルに対して、乱れの長さスケー ルの評価式および経験定数の改良が加えられている。

\subsection{4 次 5 次領域 (改良 k- $\varepsilon$ モデル)}

Figure 4 は山越え気流の予測で考慮すべき種々の要 素を示したものである。山越え気流には流線の曲がり や主流方向の圧力勾配、また山陵付近における剥離、 後方での再付着等、性状の異なる様々な流れが混在し 極めて複雑である。さらに、樹木の有無による速度変 


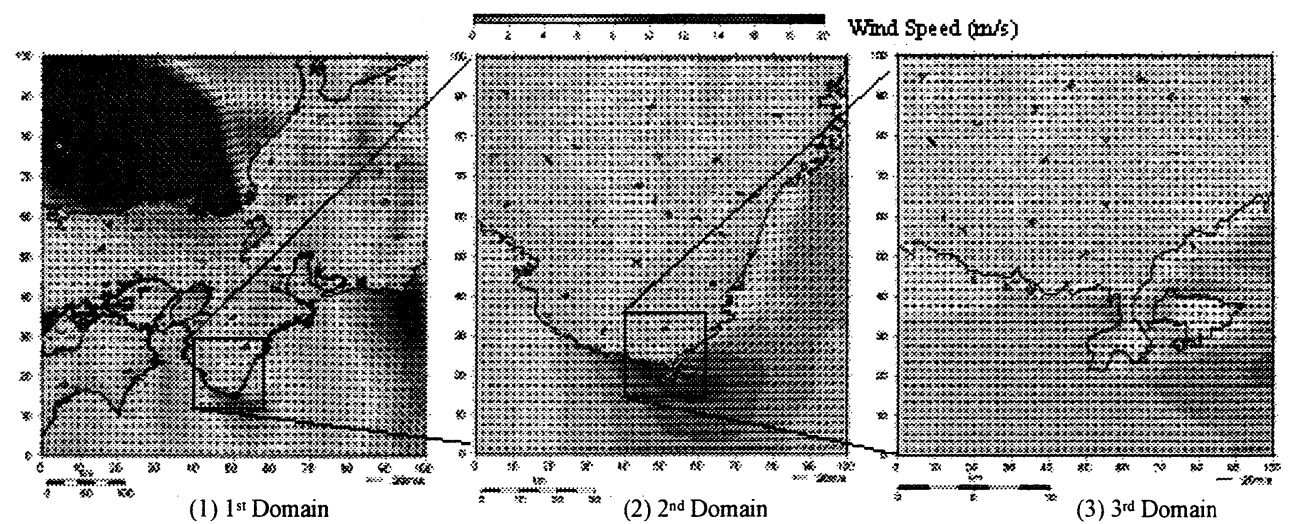

Figure 3 Numerical predictions of windfield over Siono Promontory using nesting method (March 14, 2001, 12:00, at a height of 10m above the ground.)

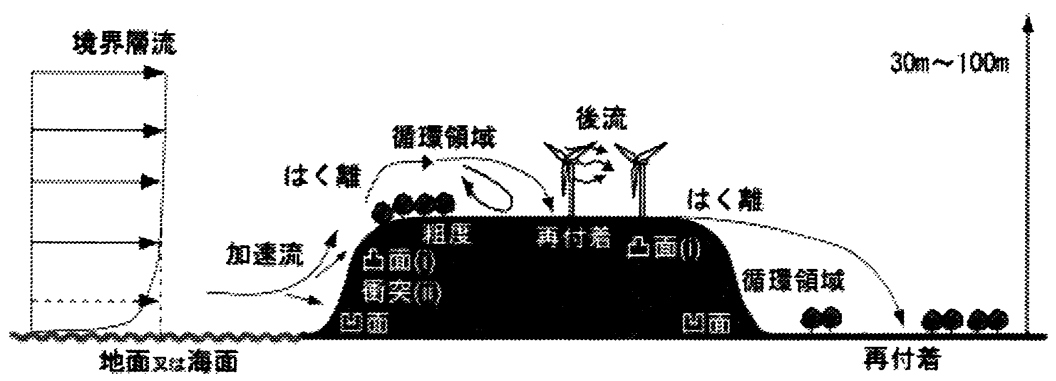

Figure 4 Factors affecting the flow around a hilly terrain (Nagano et al. )

化、乱流性状の変化も流れの構造に大きな影響を及ぼ す ${ }^{1225)}$ 。この様な流れに対して最も信頼性の高い予測 が可能なのはLES であると考えられるが、計算負荷を 考えると、年平均風速の予測にこれを利用することは、 現段階では現実的ではない。本研究では実用性の観点 から改良型の $\mathrm{k}-\varepsilon$ モデルの使用を前提として、地形ま わりの流れの高精度予測を可能とする新たなモデルの 開発を進めている。

本プロジェクトでは、当初、非線形型の $\mathrm{k}-\varepsilon$ モデル 13)-15)の利用を考え、高精度の予測が可能であることを 確認している ${ }^{14-17)}$ 。しかし、計算負荷を考えると、実 用に供するには問題が多いと判断し、比較的少ない計 算負荷で高精度の予測を可能とする線形モデルを開発 する方向で研究を進めてきた ${ }^{18)}$ 。以下にその概要を示 す。

線形型の k- $\varepsilon$ モデルでは、レイノルズストレス $\left\langle u_{i}{ }^{\prime} u_{j}{ }^{\prime}\right\rangle$ は次式で表現される。

$$
-\left\langle u_{i}^{\prime} u_{j}^{\prime}\right\rangle=v_{t}\left(\frac{\partial\left\langle u_{i}\right\rangle}{\partial x_{j}}+\frac{\partial\left\langle u_{j}\right\rangle}{\partial x_{i}}\right)-\frac{2}{3} k \delta_{i j}
$$

本稿ではく 〉はアンサンブル平均を示す。(1)式中の
渦動粘性係数 $v_{\mathrm{t}}$ は、

$$
v_{t}=C_{\mu} k \tau_{m}
$$

と表現される。ここで、 $\tau_{m}$ は乱流を特徵づける時間 スケールで市るが、本研究ではこれを長野らの提案寸 る混合タイムスケールの考え方に従って(3)式の様に 表す ${ }^{18)}$ 。すなわち、通常の $\mathrm{k}-\varepsilon$ モデルで使用される乱 れの時間スケール $\tau_{\mu}\left(\frac{k}{\varepsilon}\right)$ と平均流の速度勾配による 時間スケール $\tau_{\mathrm{s}}$ の調和平均から混合タイムスケール $\tau_{m}$ を次式で定義する注4)

$$
\begin{aligned}
& \frac{1}{\tau_{m}}=\frac{1}{2}\left(\frac{1}{\tau_{\mu}}+\frac{C_{s}}{\tau_{s}}\right) \\
& \text { ただし } \quad \tau_{\mu}=\frac{k}{\varepsilon}, \tau_{s}=\frac{1}{\sqrt{\Omega^{2}}}, \Omega^{2}=\Omega_{i j} \Omega_{j i}, \\
& \Omega_{y}=\frac{1}{2}\left(\frac{\hat{c}\left\langle u_{i}\right\rangle}{\hat{c} x_{j}}-\frac{\hat{c}\left\langle u_{j}\right\rangle}{\hat{c} x_{i}}\right) \quad, \quad C_{s}=0.4
\end{aligned}
$$

(3)式を書き直すと、以下の様に表現される。

$$
\tau_{m}=\frac{k}{\varepsilon}\left(\frac{2 R_{\mu}}{R_{\mu}+C_{s}}\right) \quad \text { (4) } R_{\mu}=\frac{1 / \sqrt{\Omega^{2}}}{k / \varepsilon}
$$




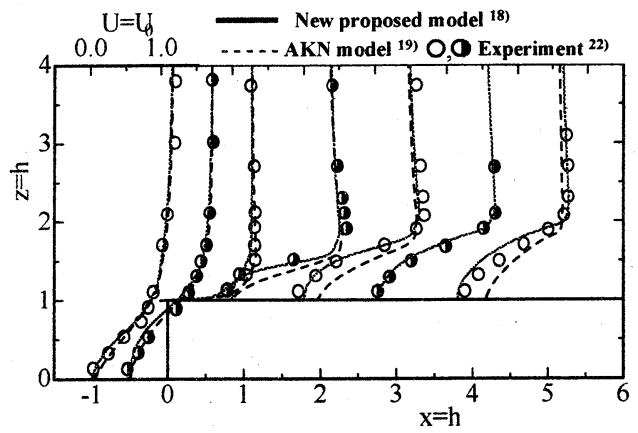

(1) Comparison between the new proposed model, $\mathrm{AKN}$ and experiment

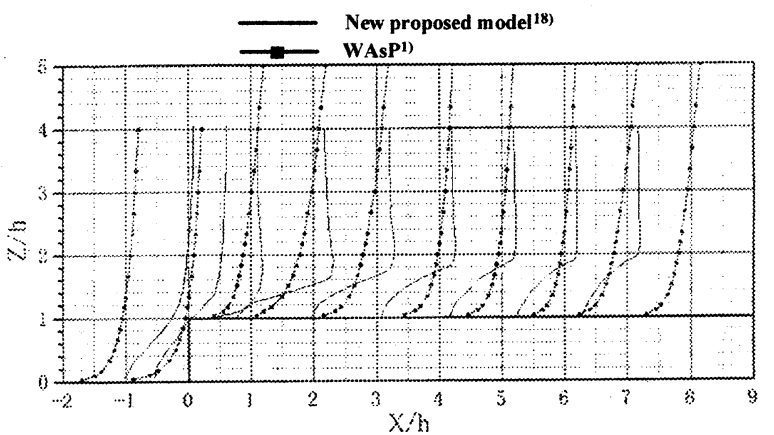

(2) Comparison between the new proposed model and WAsP

Figure 5 Comparison of mean streamwise velocity around a 2D cliff model (5th Domain)

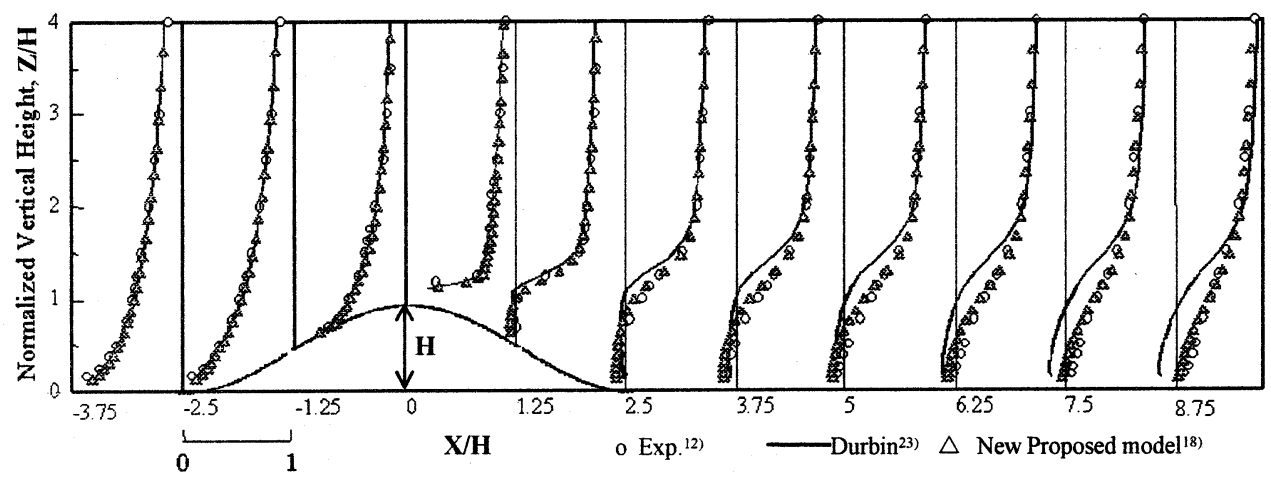

Figure 6 Comparison of mean streamwise velocity around a 2D hill model (5thDomain )

さらに、Abe-Kondo-Nagano(AKN)モデル ${ }^{19}$ における 地表付近の低 Re 効果のモデリングを組み込み、最終 的には、

$$
\begin{aligned}
& v_{t}=C_{\mu} f_{\mu} k \tau_{v} \\
& \tau_{v}=(k / \varepsilon)\left\{2 R_{\mu} /\left(R_{\mu}+C_{s}\right)+\left(45 / R_{t}^{3 / 4}\right) \exp \left[-\left(R_{t} / 100\right)^{3 / 4}\right\}\right\} \\
& \text { ここで、 } R_{t}=k^{2} / v \varepsilon
\end{aligned}
$$

また、(3)式で定義されるタイムスケール $\tau_{\mathrm{m}}$ と区別 するために、本稿では(7)式で表現されるタイムスケー ルをて と記す。

さらに、地表面粗度の影響をモデルに組み込むため、 Krogstar ${ }^{20)}$ 、Zhang $5^{21)}$ によるモデルを参考に、(6)式中 の壁面影響関数 $f_{\mu}$ と $\varepsilon$ の輸送方程式中の散逸項に含ま れる関数 $f_{\varepsilon}$ を次式で定義する ${ }^{18)}$ 。

$$
\begin{aligned}
& f_{\mu}=1-\exp \left[-\left(z^{*} / 22\right)^{2}\right]+H_{1} \\
& H_{1}=\left\{\begin{array}{l}
h^{+} \neq 0 \text { 場合 }: H_{1}=\exp \left\{\left[z^{*} /\left(0.15 h^{+}\right)\right]^{2}\right\}\left[1+\exp \left(-35 / h^{+}\right)\right] \\
h^{+}=0 \text { 場合 }: H_{1}=0
\end{array}\right. \\
& f_{\varepsilon}=\left\{1.0-0.3 \exp \left[-\left(R_{t} / 6.5\right)^{2}\right]\right\} \times\left\{1-\exp \left[-\left(z^{*} / 3.1\right)^{2}\right]\right\}+H_{2}
\end{aligned}
$$

$$
H_{2}=\left\{\begin{array}{l}
h^{+} \neq 0 \text { の場合 : } H_{2}=\sqrt{h^{+} / 15}\left[\exp \left(-5.0 z^{*} / h^{+}\right)\right] \\
h^{+}=0 \text { 場合 : } H_{2}=0
\end{array}\right.
$$

ここで、 $h$ : 地表面粗度の高さ, $h^{+}=h<u^{*}>/ v$,

$$
z^{*}=z u_{\varepsilon} / \nu, u_{\varepsilon}=(\mathrm{v} \varepsilon)^{1 / 4}
$$

Figure 5 に崖地形を対象とした本研究で開発したも デルと WAsP の予測結果およびMoss, Baker の風洞実 験結果 ${ }^{22)}$ の比較を示す。WAsP の結果は、風上コーナ 部の剥離流を全く再現しておらず、このため後方の風 速分布も大きく実験と異なる。これに対して、本プロ ジェクトで開発したモデルの結果は非常によく実験と 一致している。

Figure 6 は 2 次元山越え気流を対象とした比較であ る。ここでは、石原らの行った風洞実験 ${ }^{12)}$ と本プロジ エクトにおける開発モデル注5)およびDurbin 型 $\mathrm{k}-\varepsilon$ モ デルの比較を示している。Durbin 型k- $\varepsilon$ モデル ${ }^{23)}$ は、 建物周辺気流に適用した場合、他の多くの改良 $\mathrm{k}-\varepsilon$ モ デルに比べて高精度の予測が可能であることが、筆者 らにより確認されている ${ }^{24)}$ 。しかし、山越え気流に適 用すると、後方循環流域における乱流拡散が過小とな り、結果として後方再付着距離が極めて過大に評価さ 
Table 1 Effects of surface roughness on separating point and reattachment length ${ }^{12)}$

\begin{tabular}{c|c|c|c}
\hline $\begin{array}{c}\text { Surface } \\
\text { Condition }\end{array}$ & $\begin{array}{c}\mathrm{Xs} / \mathrm{H} \\
\text { (Separation) }\end{array}$ & $\begin{array}{c}\mathrm{Xr} / \mathrm{H} \\
\text { (Recirculation) }\end{array}$ \\
\hline Smooth & 1.1 & 4.6 \\
Rough & 0.6 & 6.4 \\
\hline
\end{tabular}

Table 2 Models for incomporating aerodynamic effects of tree canopy ${ }^{27}$

\begin{tabular}{|c|c|c|}
\hline$F_{i}$ & $\eta C_{f i} a\left\langle u_{i}\right\rangle \sqrt{\left\langle u_{j}\right\rangle^{2}}$ & (13) \\
\hline$F_{k}$ & $\left\langle u_{i}\right\rangle F_{i}$ & (14) \\
\hline$F_{\varepsilon}$ & $\frac{\varepsilon}{k} \cdot C_{p \varepsilon} F_{k}$ & (15) \\
\hline
\end{tabular}

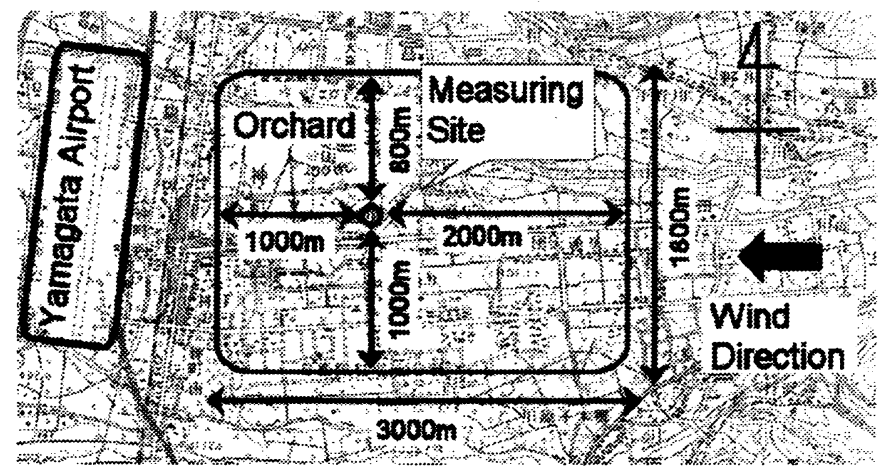

(1) Computational domain $(3000 \mathrm{~m} \times 1800 \mathrm{~m} \times 200 \mathrm{~m})$

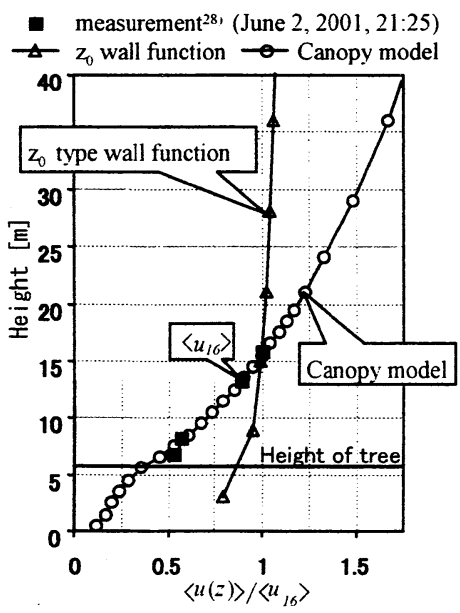

2) Vertical profiles of normalized mean streamwise velocity above tree

Figure 7 Comparison of vertical velocity profiles above tree canopy ( Higashine, Yamagata )

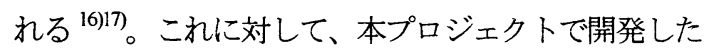
モデルを用いると著しい精度の改善がもたらされる。

\section{3 樹木 Canopy のモデリング}

樹木の有無による地表面ラフネスの相違は山岳まわ りの流れに極めて大きな影響を及ぼす。石原らは樹木 に相当するラフネスのある場合とない場合の山越え気 流の性状の差異に関して詳細な実験を行っている ${ }^{12) 。 ~}$ Table 1 にその結果を示す。樹木のない山に比べて、表 面が樹木に覆われた山の場合、剥離点が風上に移動し、 この影響で後方再付着点が後方に移動する。筆者らは そのメカニズムについて LES により検討を加えてい る $^{25)}$ 。

このような、樹木の流体力学的効果を正確に再現す るために、本プロジェクトでは樹木 Canopy モデルの

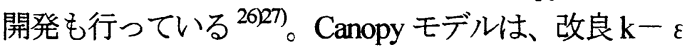
モデルを基礎として、その方程式系に Table 2 に示す樹 木の効果を表す項を付加するという形式となっている。 具体的には、樹木による風速低減効果の影響を平均流 の輸送方程式に付加項一 $F_{i}$ を付け加えることによって 表わし、樹木による乱れの増加の影響を $\mathrm{k}$ の輸送方程 式の付加項 $F_{k}$ によって与え、それに伴う粘性消散率 $\varepsilon$
の増加を $\varepsilon$ の輸送方程式に付加項 $\mathrm{F}$ ，を付け加えるこ とにより表す。Table 2 にそれぞれの付加項を示す。

このモデルを用いて、山形県東根市の果樹園地帯 (Figure 7(1))の上空風を解析し、松島の行った観測結 果 $^{28)}$ と比較:した注6)。測定点の周囲には、東側に約 $2 \mathrm{~km}$ 、 西に約 $1 \mathrm{~km}$ 、北に約 $0.8 \mathrm{~km}$ 、南に約 $1 \mathrm{~km}$ の範囲で樹高 $5 \mathrm{~m}$ 程度のリンゴやサクランボの果樹園が広がってい る。ここでは、東風の時の風速分布に関する解析結果 と観測結果を比較している。また、参考のために、図 中には $\mathrm{z}_{0}$ 型の対数則注7) に基づく wall function $\left(\mathrm{z}_{0}=0.5 \mathrm{~m}\right)$ を利用した結果も示している。

Figure 7(2)では、野外観測における最も高い測定点で ある $16 \mathrm{~m}$ の平均風速 $<u_{16}>$ で基準化した風速鉛直分布 を比較しているが、本プロジェクトで開発した Canopy モデルの結果は良く実測結果を再現している。これに 対して、 $z_{0}$ 型の wall function を用いた結果はその分布 を性状が大きく異なっている。WAsP や AVENUでは、 Canopy モデルではなく $z_{0}$ 型の wall function が採用さ れており、この面からも既往のモデルの限界が指摘さ れる。

\section{4 貔測データとの比較}

以上の成果を用いて、現在観測を行っている潮岬周 


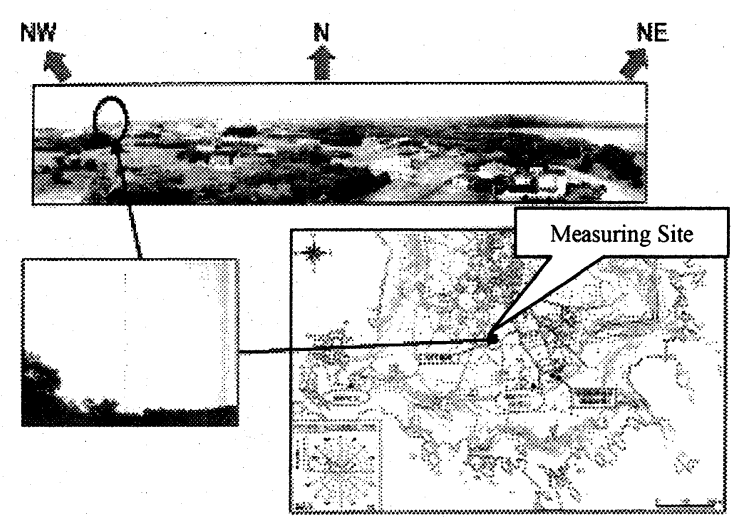

(1) Situation around measuring site

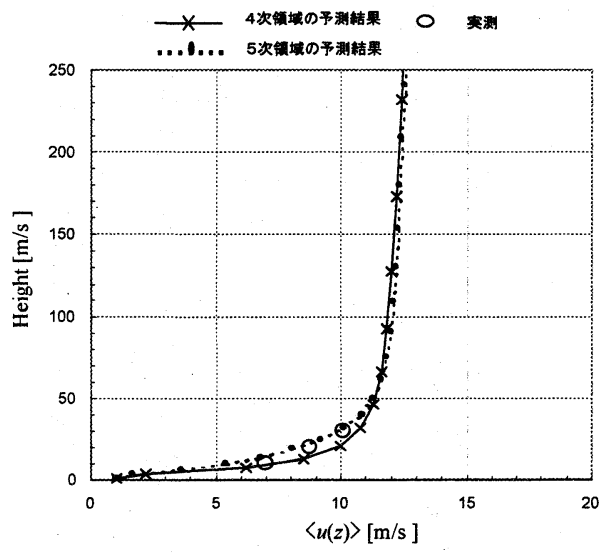

(2) Vertical profile of mean streamwise velocity

Figure 8 Comparison of vertical velocity profiles above Siono Promontory, Wakayama (Sep. 2, 2000, 15:00)

辺(Figure 8(1))の風況予測を行い、観測值と比較した結 果を Figure 8(2)に示す。ここでは 2000 年 9 月 2 日を対 象として 1 次〜 5 次までの Nesting 計算を実行している。 Figure 8(2)は 15 時の風速分布を比較したものである。 4 次領域、 5 次領域の解析では Table 2 の Canopy モデ ルを組み込んでいる注8)。Figure 8(2)に計算結果を示す。 5 次領域のモデルを接続することによって、予測值が より観測值に近づき、よく一致している。

4.まとめ

本稿では、我が国のような急峻な山岳地形の多い国 土において適切な風車の立地選定を行うための局所風 況予測モデルの開発をめざして、現在進行中の NEDO の研究プロジェクトの概要を紹介した。本プロジェク トでは年平均風速を $10 \%$ 以内の誤差で予測すること を目標とし、広領域のための気象モデルの開発、山岳 周辺のミクロスケールのための工学モデルの開発を並 行して進めるとともに、 5 段階 Nesting でこれらを接続
する手法についても検討を加えている。同時に、風洞 実験、野外実測により検証用のデータを採取し、モデ ルの精度検討も進めている。プロジェクトは後 1 年で 終了するが、風工学分野におけるこれまでの研究の蓄 積を活かした実用性の高い高精度の予測システムの完 成を目指し、研究を進めているところである。その最 終成果については、別の機会に詳しく報告したいと考 えている。

\section{[ 粼辞]}

本稿は、新エネルギー・産業技術総合開発機構（NEDO）か ら委託された離島用風力発電システム等技術開発の中の局所的 風況予測モデルの開発の活動について、長野靖尚教授 (名工大)、 中西幹郎助教授 (防衛大)，大塚清敏博士（大林組）をはじめと するプロジェクト研究メンバー各位注 ${ }^{22}$ 研究成果を筆者らの責 任でまとめたものである。本稿作成に際してご協力頂いたメン バー各位に謝意を表する。

\section{[ 注 ]}

注1) Jackson-Hunt の線形理論 ${ }^{3)}$ では、大気境界層を内層（inner layer）と外層（outer layer）に分ける (Figure 9)。

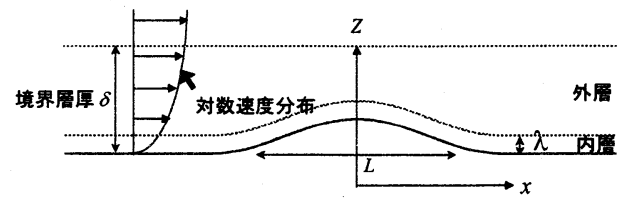

Figure 9 Flow regimes for turbulent flow over a hill)

ここで、内層とは境界層下部の地表に近い薄い層であり、 地表付近の流れの変化により生じる Reynolds 応力が支配 的な影響を及ぼす。代表的長さスケールは粗度長 $z_{0}$ と内層 の厚さ入であると考える。外層は内層上部の境界層の中で、 地形による流れの変化が生じる高さまでの範囲の層であ る。厚さは丘陵の水平スケール L 程度であり、境界層厚さ $\delta$ よりも大きい場合も小さい場合もある。Jackson-Hunt の 理論では、この層では Reynolds 応力の影響は無視し得ると 考え、代表的長さスケールはLおよび 0 であるとする。こ の理論では、起伏のある地表面上の流れは、無限遠の上流 側における風速の鉛直分布を起伏に合わせて平行移動さ せたものに、起伏による加速・減速が摄動として付加され ると考える。そして、外層ではReynolds 応力の効果を考慮 せず、線形化されたポテンシャル流の方程式を解く。そし て内層の地表面付近の風速の摂動は、ポテンシャル理論で 求められた圧力分布と内層内の Reynulds 応力項およひ線 形化された移流項のバランスにより決定される。このよう な理論に基づく解析手法が急峻な地形周边の流れ、特に剥 離を伴う流れの予測に適用困難であることは明らかであ ると考えられる。

注2) 本プロジェクトの研究メンバーは以下の通り。 
村上周三(研究代表, 慶応大学)、長野靖尚(名工大)、加藤信 介(東大生研)、持田灯(東北大)、中西幹郎(防衛大)、加藤和 彦(NEDO)、信江豊(NEDO)、斉藤隆雄(大林組)、片岡浩人(大 林組)、大塚清敏(大林組)、布施木徹(ビートラポ)、中尾徹 (E\&Eソリューションズ)、臼井健(E\&Eソリューションズ)、 加藤秀樹( $E \& E$ ソリューションズ)、林宏典(日本気象協会)、 植松孝彦 (日本気象協会)、鈴木靖 (日本気象協会)、鈴木 晋之丞 (日本気象協会)、佐々木律子 (日本気象協会)

注 3)別途、非静力学モデルも用意しているが、計算負荷が増加

する割りに精度向上がめざましくないので、当面は静力 学モデルを用いる。

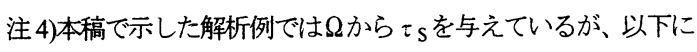
示すように歪速度テンソル $S_{i j}$ からて $\mathrm{s}$ を与えるモデルにつ いても精度の検討を行っている。

$$
\tau_{s}=\frac{1}{\sqrt{S^{2}}} \quad S^{2}=S_{i j} S_{j i} \quad S_{i j}=\frac{1}{2}\left(\frac{\partial\left\langle u_{i}\right\rangle}{\partial x_{j}}+\frac{\hat{c}\left\langle u_{j}\right\rangle}{\partial x_{i}}\right)
$$

さらに、S と $\Omega$ を組み合わせて $\tau_{\mathrm{S}}$ を与えるモデルも考案し、 $\Omega$ 単独やS 単独から $\mathrm{s}$ を与えるモデルに比べて、予測精度 が改善されることを確認している。

注 5)本解析では地表面境界条件として $\log$ law 型の wall function を用い、高Re 領域のみを対象としているので、(6)〜(11)式 の低 Re 効果を組み込んだモデルではなく、(1)〜(5)式を利 用している。

注 6)本解析では既往の研究を参考に ${ }^{29-31)} 、 C_{f}=0.2, a=0.83$ とした。 また、現地の状況を考えて、 $\eta=0.4$ とした。 $C_{p_{t}}$ については 単独樹木モデル周辺の気流分布を対象として筆者らにより 最適化された值(2.0)を用いた27。

注 7)地表面の摩擦速度〈u* $\rangle(16)$ 式 $\varepsilon$ 方程式中の地表面第 1 セルの $\varepsilon\left(\varepsilon_{\mathrm{p}}\right)$ を(17)式 $\mathrm{k}$ 方程式中の地表面第 1 セルの $\varepsilon(\bar{\varepsilon})$ を(18) 式により与えた。また本解析では $z_{0}=0.5 \mathrm{~m}$ とした

$$
\begin{gathered}
\frac{\left\langle u_{i}\right\rangle_{p}}{\langle u .\rangle}=\frac{1}{\kappa} \ln \frac{(1 / 2) h_{p}}{z_{0}} \quad \text { (16) } \quad \varepsilon_{p}=\frac{c_{\mu}^{3 /+k} k^{3 / 2}}{\kappa(1 / 2) h_{p}} \\
\bar{\varepsilon}=\frac{c_{\mu}^{3 /+k}{ }^{3 / 2}}{k h_{p}} \ln \frac{h_{p}}{z_{0}} \quad \text { (18) }
\end{gathered}
$$

但し、 $C_{\mu}=0.09, \kappa=0.4$,

$\left\langle u_{t}\right\rangle_{p}$ : 地表面第一七ルの接線方向速度の時間平均值

$h_{p} \quad$ : 地表面第 1 セル $\sigma z$ 方向の幅

$\varepsilon_{p}:$ :地表面第 1 セルの $\varepsilon$

$\bar{\varepsilon} \quad$ :地表面第 1 セルにおける $\varepsilon$ 空間平均值

注 8)高さ $5 \mathrm{~m}$ の樹木で一様に覆われてると仮定し、Canopy モデ ルに含まれる樹木に関するパラメータはそれぞれ、 $a=1.0$ 、 $C_{f}=0.2 、 \eta=0.6$ とした。

\section{References}

1) S. Sandström, WASP-a comparison between model simulations and measurements, Wind Energy Report WE 94:2, Dept. of Meteorology, Uppsala University, 1994.

2) P.B.S. Lissaman, D.R. Foster, J.H. Rumbaugh, C. Boulder. Technical description of AVENU, Proc. Annual Meeting of ASES, Denver, Colorado, June 1989., pp.19-22,

3) P.S. Jackson, J.C.R. Hunt, Turbulent wind flow over a low hill, Quart. J. Roy. Met. Soc. 101, 1975, pp.929-955.

4) J. L. Walmsley, P. A. Tayor, Boundary-layer flow over topography, Impact of the Askervein study, Boundary-Layer Meteorol. Vol. 78, 1996, pp.291-320.

5) 大样光, 河井宏充, 藤波潔, 風に及ぼす地形の影響に関す る研究, 日本建築学会大会学術講演梗概集, 1998 , pp.119-120.

6) 石原孟，日比一喜，急峻な山を越える乱流場の数值予測，日 本風工学会誌, 2000.4, vol.83,pp.175-188

7) 大津朋博, 加藤信介, 村上周三 高橋岳生, M.F. Yasin, 風力 発電用風車建設最適地検討用の局所風況予測モデルに関す る風洞模型実験 (その2)：二次元丘陵模型周囲の各種乱流 統計量の測定, 日本建築学会大会学術講演梗概集,噮境工学 I, 2001.9, pp.755-756

8) M. F. Yassin, S. Kato, S. Murakami, R. Ooka, T. Takahashi, T. Ohtsu, Wind Tunnel Study on Prediction Method of Wind Characteristics over Local Topography for Suitable Site of Wind Power Station (Part 3) : Turbulence Characteristics of Flow over Two-Dimensional Step Model, Summaries of Technical Papers of Annual Meeting AIJ, Environmental Engineering I Sep. 2001, pp.757-758

9) 高橋岳生, 加藤信介, 村上周三, 大津朋博, M.F. Yassin, 風力 発電用風車建設最適地検討用の局所風況予測モデルに関す る風洞模型実験 (その 4): 大気安定度の違いによるStep 状 地形周りの流れの変化, 日本建築学会大会学術講演梗概集, 環境工学 I, 2001.9, pp.759-760

10) G.L. Mellor, T. Yamada, Development of a turbulence closure model for geophysical fluid problem, Rev. Geophys. Space Phys., vol. 20, No. 4, 1982, pp.851-875.

11) M. Nakanishi, Improvement of the Mellor-Yamada turbulence closure model based on Large-Eddy Simulation data, Boundary Layer Meteorol. 99, 2001, pp.349-378.

12）孟岩, 日比一喜, 急峻な山を越える乱流境界層に関する実 験的研究, 第 15 回風工学シンポジウム論文集, 1998 , pp.61-66

13) T.H. Shih, J. Zhu, J.L. Lumley, A realizable Reynolds stress naralgebraic equation model, NASA TM-105993, 1993.

14) 入門知子, 平松崇嘉, 服部博文,長野靖尚, 流線の曲がりの 影響を受ける乱流場に関する研究, 第 14 回数值流体シンポ ジウム論文集, 2000, pp.1-3, 
15) T. Irikado, H, Hattori, $Y$, Nagano, Prediction of turbulent flow over acurved hill, Proceedings of the $4^{\text {th }}$ JSME-KSME Thermal Engineering Conference, vol..2, Oct. 2000.., pp.473-478

16) Y.F. Lun, A. Mochida, S. Murakami, H. Yoshino, T. Shirasawa, Numerical simulation of flow over topographic features by revised k- $\varepsilon$ models, Fifth Asia-Pacific Conference on Wind Engineering (APCWE V), Kyoto, October, 2001, pp.21-24

17) Y.F. Lun, A. Mochida, H. Yoshino S. Murakami, CFD Prediction of Flow over A Blunt Body By Revised k- $\varepsilon$ Model, 第 15 回 数值流体力学シンポジウム講演要旨集, 2001,p.89

18）長野靖尚, 服部博文, 入門知子, 乱流モデルによる複雑地形 上の風況予測, Proceeding of the TED-Conf., JSME, 2001

19) K. Abe, T. Kondoh, Y. Nagano, A new turbulence model for predicting fluid flow and heat transfer in separating and reattaching flows - I. Flow field calculations, Int. J. Heat Mass Transfer, vol.. 37, No.1, 1994, pp.139-151

20) P. Krogstad, Int. AIAA J., 29, 1991, pp. 888-894

21) H. Zhang, M. Faghri, F. White, Int. J. Fluid Engng., 118, 1996, pp. $255-259$

22) W.D. Moss, S. Baker, Re-dirculating flows associated with two-dimensional steps, Aeronaut. Quarterly, Aug. 1980, 151-172

23) P.A. Durbin, Technical Note: On the k- $\varepsilon$ stagnation point anomaly, Int. J. Heat and Fluid Flow, 17, 1996, pp.89-90.

24）富永禎秀, 持田灯, 村上周三, 大岡龍三, 佐脇哲史, 各種改 良 k- $\varepsilon$ モデルによる高層建物周辺気流の CFD 解析, 第 16 回 風工学シンポジウム論文集, 2000, pp.155-160

25）李春鉉, 持田灯, 村上周三, 加藤信介, 飯塚悟, LES による 地形まわりの局所風況の予測(その 1): 2 次元山越え気流を 対象とした地表面粗度の影響の検討, 日本建築学会大会学 術講演梗概集, 2000, pp.699-700

26）加藤敦子, 持田灯, 吉野博, 村上周三, 大岡龍三, 吉田伸治, CFD に基づく都市・建築環境解析における Grid Scale より 小さい気流障害物のモデル化一既往の研究の Review一, 日本建築学会東北支部研究報告会, 2000,pp.329-332

27) 加藤敦子, 持田灯, 吉野博, 村上周三, 植生 Canopy モデル を組み込んだ $\mathrm{k}-\varepsilon$ モデルによる単独樹木周辺の風速分布の 予測, 日本建築学会大会学術講演梗概集, 2001,pp.929-930

28）松島大, 条植された果樹園における地表面粗度の風向依存 性, 農業工学関連 4 学会 2002 年度合同大会講演要旨

29) 近藤純正,地表面に近い大気の科学、東京大学出版, 2001, p. 45

30) Kondo, J., Watanabe, T., Studies on the bulk transfer coefficients over a vegetated surface over a meltilayer energy budget model, Journal of the Atmospheric Sciences, vol.49, No.23, 1992, pp.2183-2199

31) Wilson, N. R., Shaw, R. H., A higher order closure model for canopy flow, Journal of Applied Meteorology, vol. 16, 1977, pp.1197-1205 